\title{
NORDITERPENES FROM JUNIPERUS CHINENSIS
}

\author{
Ching-Kuo Lee, Jim-Min Fang and Yu-Shia Cheng* \\ Department of Chemistry, National Taiwan University, Taipei, Taiwan 106, Republic of China
}

(Received 10 August 1994)

Key Word Index-Iuniperus chinensis; Cupressaceae; norditerpenes; norabietane-type; norpimaranetype.

\begin{abstract}
One norpimarane and 11 norabietanes were isolated from the leaves of Juniperus chinensis. The new compounds include 19-norabieta-8,11,13-trien-4-yl formate, 18-norabieta-8,11,13-triene-4-hydroperoxide, 19-norabieta-8,11,13-triene-4-hydroperoxide, 4-hydroxy-18-norabieta-8,11,13-trien-7-one, 4-hydroxy-19-norabieta-8,11,13-trien-7-one, 4-hydroperoxy-19-norabieta-8,11,13-trien-7-one, 7 $\alpha$-hydroxy-19-norabieta-8,11,13-triene-4hydroperoxide, 19-norabieta-7,13-dien-4-ol and 13 $\beta, 14 \beta$-epoxy-4-hydroxy-19-norabiet-7-en-6-one.
\end{abstract}

\section{INTRODUCTION}

Juniperus chinensis is a common ornamental tree [1]. Hinokiflavone and kayaflavone have been previously reported in this plant $[2,3]$. We recently isolated 13 lignans, a secoditerpene and 46 diterpenes in addition to other components from the bark and leaves [4-7]. The diterpenes include labdane-, abietane-, sempervirane-, totarane- and chinane-types. Labdane-type diterpenes are rich in the bark, whereas abietane-type diterpenes predominate in the leaves. A norditerpene, 15-oxo-16norabieta-7,13-dien-19,6 $\beta$-olide, and a bisnorditerpene, 15,16-bisnor-8,17-epoxy-13-oxolabd-11E-en-19-oic acid were also found, respectively, in the leaves and bark. We report here further 12 norditerpenes, including a norpimarane and 11 norabietanes, found in the leaves of J. chinensis.

\section{RESULTS AND DISCUSSION}

The acetone-soluble part of the leaves of $J$. chinensis was extracted with ethyl acetate. The extract was subjected to repeated column chromatography and HPLC to give norditerpenes 1-12. Compound 1 was identified as 18-norpimara-8(14),15-dien-4-ol by analysis of its physical and spectral properties (mp. [ $\alpha]$, MS and ${ }^{1} \mathrm{H}$ NMR) [8]. The ${ }^{13} \mathrm{C}$ NMR signals were assigned by means of HMBC experiment (Table 1).

Epimers 2 and 3 were identified as 18-norabieta8,11,13-trien-4-ol $[9,10]$ and 19-norabieta-8,11,13-trien4-ol [10], respectively. These nordehydroabietanes exhibited the characteristic ABX patterns of aromatic protons in their ${ }^{1} \mathrm{H}$ NMR spectra. The Me-10 in 3 appeared at a lower field $(\delta 1.29)$ than that in the epimer $2(\delta 1.13)$

*Author to whom correspondence should be addressed.<smiles>C=CC1C=C2CCC3C(C)(O)CCCC3(C)C2CC1</smiles>

1<smiles>CC(C)C1=CC2=CCC3C(CCCC3(C)O)C2CC1</smiles>

11

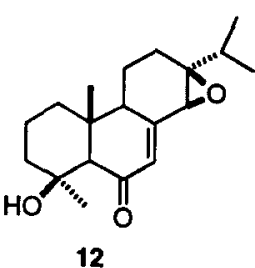

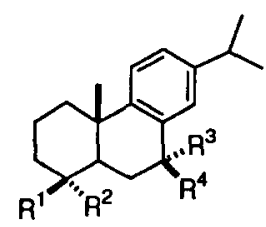

$\begin{array}{lllll} & \mathrm{R}^{1} & \mathrm{R}^{2} & \mathrm{R}^{3} & \mathrm{R}^{4} \\ \mathbf{2} & \mathrm{CH}_{3} & \mathrm{OH} & \mathrm{H} & \mathrm{H} \\ \mathbf{3} & \mathrm{OH} & \mathrm{CH}_{3} & \mathrm{H} & \mathrm{H} \\ \mathbf{4} & \mathrm{OCHO} & \mathrm{CH}_{3} & \mathrm{H} & \mathrm{H} \\ \mathbf{5} & \mathrm{CH}_{3} & \mathrm{OOH} & \mathrm{H} & \mathrm{H} \\ \mathbf{6} & \mathrm{OOH} & \mathrm{CH}_{3} & \mathrm{H} & \mathrm{H} \\ 7 & \mathrm{CH}_{3} & \mathrm{OH} & =\mathrm{O} & \\ 8 & \mathrm{OH} & \mathrm{CH}_{3} & =0 & \\ 9 & \mathrm{OOH} & \mathrm{CH}_{3} & =\mathrm{O} & \\ 10 & \mathrm{OOH} & \mathrm{CH}_{3} & \mathrm{OH} & \mathrm{H}\end{array}$

owing to the deshielding effect of the $4 \beta$-hydroxyl group. The C-4 in 2 appeared at a lower field $(\delta 52.5)$ than that in $3(\delta 48.7)$.

Compound 4 was isolated in a small amount. The exact mass at $m / z 300.209$ indicated the molecular formula $\mathrm{C}_{20} \mathrm{H}_{28} \mathrm{O}_{2}$. By analysis of the IR and NMR spectra, 4 was determined to be 19-norabieta-8,11,13-trien-4-yl formate, the formate of 3. The IR absorption at 
Table 1. ${ }^{13} \mathrm{CNMR}$ spectral data of compounds 1-12 $\left(\mathrm{CDCl}_{3}\right.$ solution, $\delta$ values in ppm)

\begin{tabular}{|c|c|c|c|c|c|c|c|c|c|c|c|c|}
\hline $\mathrm{C}$ & 1 & 2 & 3 & $4^{*}$ & 5 & 6 & 7 & 8 & 9 & 10 & 11 & 12 \\
\hline 1 & 38.6 & 38.0 & 38.2 & 38.0 & 37.7 & 38.5 & 37.2 & 37.2 & 37.4 & 38.1 & 38.6 & 37.7 \\
\hline 2 & 18.9 & 20.5 & 18.5 & 18.2 & $20.0^{\mathrm{a}}$ & $18.5^{\mathrm{a}}$ & 20.1 & 18.0 & 17.9 & 18.3 & 18.0 & 17.1 \\
\hline 3 & 42.9 & 42.7 & 40.8 & 36.0 & 35.3 & 34.8 & 42.3 & 40.7 & 34.3 & 34.7 & 41.2 & 39.8 \\
\hline 4 & 72.4 & 72.5 & 72.2 & 84.7 & 84.9 & 84.1 & 71.6 & 71.4 & 83.1 & 84.0 & 71.6 & 69.6 \\
\hline 5 & 56.4 & 52.5 & 48.7 & 50.8 & 45.4 & 50.6 & 51.0 & 48.1 & 49.1 & 44.8 & 48.9 & 62.4 \\
\hline 6 & 21.6 & 18.0 & 18.0 & 18.2 & $17.9^{\mathrm{a}}$ & $18.4^{\mathrm{a}}$ & 35.0 & 35.5 & 35.3 & 28.1 & 27.5 & 202.8 \\
\hline 7 & 35.6 & 30.3 & 29.4 & 29.4 & 30.0 & 30.2 & 199.2 & 199.6 & 199.4 & 68.3 & 120.8 & 131.4 \\
\hline 8 & 136.6 & 134.8 & 134.7 & 134.5 & 134.8 & 134.5 & 130.6 & 130.9 & 130.7 & 135.7 & 135.7 & 155.2 \\
\hline 9 & 50.3 & 145.6 & 145.6 & 146.4 & 146.3 & 146.4 & 152.8 & 153.0 & 152.8 & 146.4 & 49.9 & 51.3 \\
\hline 10 & 39.0 & 38.2 & 37.2 & 37.3 & 38.3 & 37.3 & 38.6 & 37.5 & 37.6 & 37.6 & 34.8 & 43.8 \\
\hline 11 & 20.3 & 124.5 & $123.8^{\mathrm{a}}$ & 124.0 & 124.5 & 124.2 & 123.9 & 123.5 & 123.7 & 127.6 & 22.6 & 15.4 \\
\hline 12 & 34.5 & 123.9 & $123.9^{\mathrm{a}}$ & 124.0 & 123.9 & 123.8 & 132.6 & 132.4 & 132.5 & 126.6 & 23.0 & 23.4 \\
\hline 13 & 37.4 & 146.3 & 146.8 & 145.9 & 145.7 & 145.6 & 146.8 & 146.7 & 146.8 & 146.5 & 145.3 & 64.4 \\
\hline 14 & 129.1 & 127.0 & 126.8 & 126.8 & 127.0 & 126.9 & 125.0 & 125.0 & 125.1 & 124.5 & 122.5 & 58.8 \\
\hline 15 & 148.9 & 33.4 & 33.4 & 33.5 & 33.5 & 33.5 & 33.6 & 33.6 & 33.6 & 33.5 & 34.9 & 33.4 \\
\hline 16 & 110.1 & 23.9 & 24.0 & 24.0 & 23.9 & 24.0 & 23.7 & 23.8 & 23.8 & 23.8 & 20.9 & 17.6 \\
\hline 17 & 26.0 & 23.9 & 24.0 & 24.0 & 23.9 & 24.0 & 23.8 & 23.8 & 23.8 & 24.0 & 21.4 & 17.9 \\
\hline 18 & & & 30.8 & $26.1^{\mathrm{a}}$ & 24.7 & & & 30.1 & 23.8 & 24.8 & 30.6 & 31.0 \\
\hline 19 & 23.5 & 22.9 & & & & 24.4 & 22.7 & & & & & \\
\hline 20 & 14.5 & 24.5 & 24.4 & $24.6^{\mathrm{a}}$ & 18.2 & 25.3 & 22.6 & 23.9 & 24.6 & 24.4 & 13.3 & 13.9 \\
\hline
\end{tabular}

${ }^{*}$ The ${ }^{13} \mathrm{C}$ signals of the formyl group in 4 appeared at $\delta 160.5$.

${ }^{a}$ The assignments can be interchanged.

$1713 \mathrm{~cm}^{-1}$, a proton signal at $\delta 8.10(s)$ and a carbon signal at $\delta 160.5(d)$ were attributable to the moiety of formic ester. The C-4 signal appearing at $\delta 84.7$ was in agreement with the structure. The Me-10 in 4 occurred at a rather low field $\delta 1.25$ owing to the strong deshielding effect of the formate group. A $7 \%$ NOE of the formate proton was observed by irradiation of Me-10, further supporting the stereochemistry.

Compound 5 showed a parent ion [M] ${ }^{+}$at $\mathrm{m} / z 288$ corresponding to a molecular formula $\mathrm{C}_{19} \mathrm{H}_{28} \mathrm{O}_{2}$. The ${ }^{1} \mathrm{H}$ NMR spectrum of 5 was similar to that of 2 , the chemical shift of C-4 in $5(\delta 84.9)$ was, however, larger than that in $2(\delta 72.5)$. We concluded that 5 is 18norabieta-8,11,13-triene-4-hydroperoxide. Compound 6, $[\mathrm{M}]^{+}$at $m / z$ 288, was assigned as 19-norabieta-8,11,13triene-4-hydroperoxide, an epimer of 5. Owing to the deshielding effect of the $4 \beta$-hydroperoxy group [12], the Me-10 of 6 appeared at a lower field $\delta 1.25$ than the corresponding signal of 5 (at $\delta 1.16$ ). The axial Me-4 of 5 occurred at $\delta 1.21$, whereas the equatorial Me-4 of 6 occurred at lower field $(\delta 1.34)$.

Compound $7\left(\mathrm{C}_{19} \mathrm{H}_{26} \mathrm{O}_{2}\right)$ showed an IR absorption at $1666 \mathrm{~cm}^{-1}$ attributable to a conjugated carbonyl group. Three aromatic protons of $\mathbf{A B X}$ pattern appeared at $\delta 7.26(d, J=8.1 \mathrm{~Hz}), 7.37(d d, J=8.1,1.9 \mathrm{~Hz})$ and 7.85 $(d, J=1.9 \mathrm{~Hz})$, an indication for a dehydroabietanone having the oxo group at C-7. The signal at $\delta 71.6$ was attributable to C-4 having a hydroxyl substituent. Compound 8 exhibited an IR absorption at $1666 \mathrm{~cm}^{-1}$ and three signals at $\delta 7.27(d, J=8.2 \mathrm{~Hz}), 7.37(d d, J=8.2$, $2.1 \mathrm{~Hz})$ and $7.85(d, J=2.1 \mathrm{~Hz})$ similar to the spectral properties of 7 . Epimers 7 and 8 were assigned as 4-hydroxy-18-norabieta-8,11,13-trien-7-one and 4-hydroxy19-norabieta-8,11,13-trien-7-one, respectively. Com- pared with 8, epimer 7 having a $4 \alpha$-hydroxyl group displayed Me-10 at a higher field ( $\delta 1.26$ vs $\delta 1.33)$ and C-5 at a lower field ( $\delta 51.0$ vs $\delta 48.1)$ in the NMR spectra. The stereochemistry of $\mathbf{8}$ was confirmed by NOESY experiments. Thus, irradiation of Me-10 (at $\delta 1.33$ ) caused a NOE on H-6 $\beta$ (at $\delta 2.76$ ) and irradiation of Me-4 (at $\delta 1.22$ ) caused NOE effects of $\mathrm{H}-6 \alpha$ (at $\delta 2.85$ ) and $\mathrm{H}-5$ (at $\delta 1.91)$. Norabietanes 7 and 8 have been obtained by cobalt dehydroabietate oxidation [11], whereas this is the first report of their occurrence in nature.

Compound $9\left(\mathrm{C}_{19} \mathrm{H}_{26} \mathrm{O}_{3}\right)$, exhibited the exact mass $[\mathrm{M}]^{+}$ion at $\mathrm{m} / \mathrm{z} 302.187$ and an IR absorption at $1659 \mathrm{~cm}^{-1}$ attributable to a conjugated ketone. Its structure was readily determined to be 4-hydroperoxy-19. norabieta-8,11,13-trien-7-one. The $\mathrm{H}-14$ resonance occurred as a doublet $(J=1.9 \mathrm{~Hz})$ at $\delta 7.84$. Irradiation of Me-4 (at 81.32 ) caused 14\% NOE effect on H-5 (at $\delta 2.08$ ), indicating that Me-4 and $\mathrm{H}-5$ are on the same face.

Compound 10 showed the exact mass ion at $\mathrm{m} / \mathrm{z}$ 304.205 corresponding to a molecular formula $\mathrm{C}_{19} \mathrm{H}_{28} \mathrm{O}_{3}$. Its structure was determined to be $7 \alpha$-hydroxy-19-norabieta-8,11,13-triene-4-hydroperoxide by spectral analyses. The equatorial $\mathrm{H}-7 \beta$ had small coupling constants ( 3.8 and $3.8 \mathrm{~Hz}$ ) with two vicinal protons. The signals at $\delta_{\mathrm{H}} 1.37$ and $\delta_{\mathrm{C}} 84.0$ were assigned to Me-4 and $\mathrm{C}-4$, respectively, by an $\mathrm{HMBC}$ experiment. Irradiation of Me-4 caused $11 \%$ NOE on H-5 (at $\delta 1.94)$, conforming with the $\alpha$-orientation of Me-4. On standing in the air, 10 (in $\mathrm{CDCl}_{3}$ solution) was gradually oxidized to give a ketone 9.

The molecular formula $\left(\mathrm{C}_{19} \mathrm{H}_{30} \mathrm{O}\right)$ of 11 was deduced from its exact mass $[\mathrm{M}]^{+}$ion at $m / z$ 274.230. An IR absorption at $3484 \mathrm{~cm}^{-1}$ and a carbinol carbon signal at 
$\delta 71.6$ indicated the presence of a hydroxyl group. Four carbon signals at $\delta 120.8,122.5,135.7$ and 145.3 as well as two vinyl protons at $\delta 5.43$ (br s) and 5.77 (s) were attributable to a conjugated diene. The structure of 11 was assigned as 19-norabieta-7,13-dien-4-ol. The Me-4 of 11 was equatorial as it had a chemical shift at $\delta 30.6$ close to the values of those signals in $\mathbf{3}$ and $\mathbf{8}$.

Compound $12\left(\mathrm{C}_{19} \mathrm{H}_{28} \mathrm{O}_{3}\right)$ showed IR absorptions at 3525 and $1661 \mathrm{~cm}^{-1}$ attributable to the hydroxyl and conjugated carbonyl groups. The structure of 12 was determined to be $13 \beta, 14 \beta$-epoxy-4-hydroxy-19-norabiet-7-en-6-one by detailed analysis of the ${ }^{1} \mathrm{H}$ and ${ }^{13} \mathrm{C}$ NMR spectra. The proton geminal to epoxy group (H-14) occurred at $\delta 3.22$ as a singlet. The $\mathrm{C}-7$ (at $\delta 131.4$ ) and $\mathrm{C}-15$ (at $\delta 33.4$ ) signals were correlated with $\mathrm{H}-14$ by an $\mathrm{HMBC}$ experiment. Irradiation of $\mathrm{H}-7$ (at $\delta 6.11$ ) caused an NOE on $\mathrm{H}-14$, supporting the assigned stereochemistry. Irradiation of H-5 (at $\delta 2.30$ ) also caused enhancements of Me-4 (at $\delta 1.33$ ) and $\mathrm{H}-9$ (at $\delta 2.10$ ).

In summary, one norpimarane 1 and 11 norabietanes 2-12 were isolated from the leaves of $J$. chinensis. Besides the hydroperoxides $5,6,9$ and 10 , isolation of the formate 4 is unique. Diterpene aldehydes having $4 \beta$-formyl groups undergo autoxidation to give norditerpene alcohols and hydroperoxides $[11,12]$. A benzene solution of abieta-8,11,13-trien-19-al stirred at $18^{\circ}$ in the air for 5 days gave 4-epidehydroabietic acid [7], 18-norabieta8,11,13-trien-4-ol (2), 19-norabieta-8,11,13-trien-4-ol (3), 4-hydroxy-19-norabieta-8,11,13-trien-7-one (8) and 19norabieta-8,11,13-trien-4-yl formate (4). It remains unclear whether the norditerpenes 1-12 are natural products or artifacts derived from autoxidation and Baeyer-Villiger oxidation of the corresponding aldehydes.

\section{EXPERIMENTAL}

Plant material. The leaves of Juniperus chinensis Linn. var. kaizuka Hort. were collected from the plant grown in the surroundings of the Department of Chemistry of the National Taiwan University. A voucher specimen is deposited in the Herbarium of our University. The leaves $(1.83 \mathrm{~kg})$ were soaked in $\mathrm{Me}_{2} \mathrm{CO}(7 \mathrm{l})$ for a week. The $\mathrm{Me}_{2} \mathrm{CO}$ extract was concd to give $90 \mathrm{~g}$ of a residue, which was diluted with $\mathrm{H}_{2} \mathrm{O}$ and extracted $\times 3$ with EtOAc. The combined EtOAc extracts were concd to give an oil $(25.5 \mathrm{~g})$, which was absorbed by $31 \mathrm{~g}$ of silica gel and then chromatographed on a column packed with $250 \mathrm{~g}$ of silica gel. By elution with gradients of hexane, EtOAc and $\mathrm{CHCl}_{3}, 12$ (2.0 mg), 1 (24 mg), 11 (3.0 mg), 3 (4.8 mg), $2(5.1 \mathrm{mg}), 8(15 \mathrm{mg}), 7$ (9.1 mg), 5 (8.6 mg), 4 (2.0 mg), $6(4.0 \mathrm{mg}), 10(13 \mathrm{mg})$, and $9(17 \mathrm{mg})$ were obtained in the ascending order of polarity. These compounds were further purified by HPLC using a Hibar Lichrospher Si 60 (Merck, $10 \mu \mathrm{m})$ column $(25 \mathrm{~cm} \times 1 \mathrm{~cm})$.

18-Norpimara-8(14), 15-dien-4-ol (1). Mp 119-120, $[\alpha]_{\mathrm{D}}^{25}+86^{\circ}\left(\mathrm{CHCl}_{3} ; c 0.8\right)$. Ref. [8], mp 119-121 $[\alpha]_{\mathrm{D}}^{22}+92^{\circ}$.
18-Norabieta-8,11,13-trien-4-ol (2). An oil, $[\alpha]_{\mathrm{D}}^{25}$ $+43.1^{\circ}\left(\mathrm{CHCl}_{3} ; c 0.51\right)$. Ref. [10], mp 89-91,$[\alpha]_{\mathrm{D}}$ $+45^{\circ}$

19-Norabieta-8,11,13-trien-4-ol (3). An oil, $[\alpha]_{\mathrm{D}}^{25}$ $+46.2^{\circ}\left(\mathrm{CHCl}_{3} ; c 0.48\right)$. Ref. $[10], \mathrm{mp} 65-67^{\circ},[\alpha]_{\mathrm{D}}$ $+50^{\circ}$.

19-Norabieta-8,11,13-trien-4-yl formate (4). An oil. $[\alpha]_{\mathrm{D}}^{25}+51.0^{\circ}\left(\mathrm{CHCl}_{3} ; c 0.07\right) . \quad$ IR $v_{\max }^{\text {Neat }} \mathrm{cm}^{-1}: 1713$ $(\mathrm{C}=\mathrm{O}) .{ }^{1} \mathrm{H}$ NMR $\left(\mathrm{CDCl}_{3}\right): \delta 1.21(d, J=6.9 \mathrm{~Hz}, \mathrm{H}-16$, 17), 1.25 (s, H-20), 1.59 ( $s, \mathrm{H}-18$ ), 2.81 (sept, $J=6.9 \mathrm{~Hz}$, $\mathrm{H}-15$ ), 6.89 (br s, H-14), 6.98 ( $b r d, J=8.2 \mathrm{~Hz}, \mathrm{H}-12$ ), 7.16 $(d, J=8.2 \mathrm{~Hz}, \mathrm{H}-11), 8.10(s,-\mathrm{OCHO})$. EI-MS $(70 \mathrm{eV})$ $\mathrm{m} / z$ (rel. int.): 300 [M] $^{+}$(28), 256 (3), 239 (100), 197 (5), 159 (8). Exact mass $[\mathrm{M}]^{+}$for $\mathrm{C}_{20} \mathrm{H}_{28} \mathrm{O}_{2}$ requires 300.2090. Found 300.2089.

18-Norabieta-8,11,13-trien-4-hydroperoxide (5). An oil, $[\alpha]_{\mathrm{D}}^{25}+34.3^{\circ} \quad\left(\mathrm{CHCl}_{3} ; c 0.2\right) . \quad$ IR $v_{\max }^{\text {Neat }} \mathrm{cm}^{-1}: 3377$ (OOH). ${ }^{1} \mathrm{H} \mathrm{NMR}\left(\mathrm{CDCl}_{3}\right): \delta 1.16(s, \mathrm{H}-20), 1.20(d$, $J=6.9 \mathrm{~Hz}, \mathrm{H}-16,17), 1.21$ (s, H-19), 2.81 (sept, $J=6.9$, $\mathrm{H}-15), 6.88(d, J=1.7 \mathrm{~Hz}, \mathrm{H}-14), 6.98(d d, J=8.2,1.7 \mathrm{~Hz}$, $\mathrm{H}-12), 7.02(d,-\mathrm{OOH}), 7.15(d, J=8.2 \mathrm{~Hz}, \mathrm{H}-11)$. EI-MS $(70 \mathrm{eV}) \mathrm{m} / \mathrm{z}$ (rel. int.): $288\left[^{[\mathrm{M}]^{+}}\right.$(23), 272 (47), 257 (52), 239 (38), 187 (100), 173 (52), 157 (28), 143 (32).

19-Norabieta-8,11,13-trien-4-hydroperoxide (6). An oil, $[\alpha]_{\mathrm{D}}^{25}+27.8^{\circ} \quad\left(\mathrm{CHCl}_{3} ; \quad c 0.2\right) . \quad$ IR $v_{\max }^{\text {Neat }} \mathrm{cm}^{-1}: 3391$ $(-\mathrm{OOH}) .{ }^{1} \mathrm{H}$ NMR $\left(\mathrm{CDCl}_{3}\right): \delta 1.20(d, J=6.9 \mathrm{~Hz}, \mathrm{H}-16$, 17), 1.25 ( $s, \mathrm{H}-20$ ), 1.34 ( $s, \mathrm{H}-18), 2.80$ (sept, $J=6.9 \mathrm{~Hz}$, $\mathrm{H}-15), 6.87(d, J=1.7 \mathrm{~Hz}, \mathrm{H}-14), 6.95(d d, J=8.2,1.7 \mathrm{~Hz}$, $\mathrm{H}-12), 7.06(s,-\mathrm{OOH}), 7.14(d, J=8.2 \mathrm{~Hz}, \mathrm{H}-11)$. EI-MS (70 eV) $\mathrm{m} / z$ (rel. int.): $288\left[\mathrm{M}^{+}(23), 272(30), 257\right.$ (40), 239 (24), 187 (100), 156 (23), 141 (22). Exact mass [M] ${ }^{+}$ for $\mathrm{C}_{19} \mathrm{H}_{28} \mathrm{O}_{2}$ requires 288.2090. Found 288.2079.

4-Hydroxy-18-norabieta-8,11,13-trien-7-one (7). An oil, $[\alpha]_{\mathrm{D}}^{25}+20.1^{\circ}\left(\mathrm{CHCl}_{3} ; c 0.9\right)$. IR $v_{\max }^{\text {Neat }} \mathrm{cm}^{-1}: 3467(\mathrm{OH})$, $1666(\mathrm{C}=\mathrm{O}) .{ }^{1} \mathrm{H}$ NMR $\left(\mathrm{CHCl}_{3}\right): \delta 1.17(\mathrm{~s}, \mathrm{H}-19), 1.21(d$, $J=6.9 \mathrm{~Hz}, \mathrm{H}-16,17), 1.26(s, \mathrm{H}-20), 1.43(m, \mathrm{H}-3), 1.54$ $(m, \mathrm{H}-1 \alpha), 1.6-1.8(\mathrm{H}-2), 1.88(m, \mathrm{H}-3 \beta), 2.10(d d, J=14.2$, $3.5 \mathrm{~Hz}, \mathrm{H}-5$ ), 2.27 (br d, $J=12.7 \mathrm{~Hz}, \mathrm{H}-1 \beta$ ), 2.58 (dd, $J=17.9,14.2 \mathrm{~Hz}, \mathrm{H}-6 \beta$ ), 2.89 (sept, $J=6.9 \mathrm{~Hz}, \mathrm{H}-15$ ), $2.96(d d, J=17.9,3.5 \mathrm{~Hz}, \mathrm{H}-6 \alpha), 7.26(d, J=8.1 \mathrm{~Hz}$, $\mathrm{H}-11), 7.37(d d, J=8.1,1.9 \mathrm{~Hz}, \mathrm{H}-12), 7.85(d, J=1.9 \mathrm{~Hz}$, H-14). EI-MS (70 eV) $m / z$ (rel. int.): $286\left[\mathrm{M}^{+}\right.$(72), 271 (13), 253 (29), 243 (28), 211 (29), 201 (100), 185 (18), 159 (64). Exact mass [M] ${ }^{+}$for $\mathrm{C}_{19} \mathrm{H}_{26} \mathrm{O}_{2}$ requires 286.1934 . Found 286.1936.

4-Hydroxy-19-norabieta-8,11,13-trien-7-one (8). An oil, $[\alpha]_{\mathrm{D}}^{25}+26.7^{\circ}\left(\mathrm{CHCl}_{3} ; c 1.5\right)$. IR $v_{\max }^{\text {Neat }} \mathrm{cm}^{-1}: 3467(\mathrm{OH})$, $1659(\mathrm{C}=\mathrm{O}) .{ }^{1} \mathrm{H}$ NMR $\left(\mathrm{CHCl}_{3}\right): \delta 1.22(s, \mathrm{H}-18), 1.23(d$, $J=6.8 \mathrm{~Hz}, \mathrm{H}-16,17), 1.33(s, \mathrm{H}-20), 1.44(d d d, J=14.0$, $14.0,3.8 \mathrm{~Hz}, \mathrm{H}-3 \alpha$ ), 1.54 (ddd, $J=13.0,13.0,3.7 \mathrm{~Hz}, \mathrm{H}-$ $1 \alpha), 1.7-1.8(\mathrm{H}-2), 1.91(d d, J=13.2,4.7 \mathrm{~Hz}, \mathrm{H}-5), 2.01(m$, $\mathrm{H}-3 \beta), 2.32$ ( $b r d, J=13.0, \mathrm{H}-2 \beta), 2.76(d d, J=18.3$, $13.2 \mathrm{~Hz}, \mathrm{H}-6 \beta$ ), $2.85(d d, J=18.3,4.7 \mathrm{~Hz}, \mathrm{H}-6 \alpha), 2.90$ (sept, $J=6.8 \mathrm{~Hz}, \mathrm{H}-15), 7.27(d, J=8.2 \mathrm{~Hz}, \mathrm{H}-11), 7.37$ $(d d, J=8.2,2.1 \mathrm{~Hz}, \mathrm{H}-12), 7.85(d, J=2.1 \mathrm{~Hz}, \mathrm{H}-14)$; EI-MS (70 eV) $m / z$ (rel. int.): $286\left[\mathrm{M}^{+}\right](100), 271$ (59), 253 (49), 211 (45), 201 (86), 185 (16), 159 (32).

4-Hydroperoxy-19-norabieta-8,11,13-trien-7-one (9). An oil, $[\alpha]_{\mathrm{D}}^{25}+70.6^{\circ}\left(\mathrm{CHCl}_{3} ; c 0.17\right) ;$ IR $v_{\max }^{\text {Neat }} \mathrm{cm}^{-1}$ : $3353,1659 .{ }^{1} \mathrm{H}$ NMR $\left(\mathrm{CDCl}_{3}\right): \delta 1.22(d, J=6.9 \mathrm{~Hz}, \mathrm{H}$ - 
16, 17), 1.29 ( $s, \mathrm{H}-20), 1.32(s, \mathrm{H}-18), 2.08(d d, J=12.3$, $5.7 \mathrm{~Hz}, \mathrm{H}-5), 2.84$ (dd, $J=18.2,12.3 \mathrm{~Hz}, \mathrm{H}-6), 2.87$ (dd, $J=18.2,5.7 \mathrm{~Hz}, \mathrm{H}-6), 2.90$ (sept, $J=6.9 \mathrm{~Hz}, \mathrm{H}-15$ ), 7.27 $(d, J=8.2 \mathrm{~Hz}, \mathrm{H}-11), 7.37(d d, J=8.2,1.9 \mathrm{~Hz}, \mathrm{H}-12), 7.84$ $(d, J=1.9 \mathrm{~Hz}, \mathrm{H}-14)$. EI-MS $(70 \mathrm{eV}) \mathrm{m} / z$ (rel. int.): 302 $[\mathrm{M}]^{+}(8), 286(26), 271(49), 253(84), 211$ (63), 201 (70), 185 (42), 43 (100). Exact mass $[\mathrm{M}]^{+}$for $\mathrm{C}_{19} \mathrm{H}_{26} \mathrm{O}_{3}$ requires 302.1883 . Found 302.1872 .

7a-Hydroxy-19-norabieta-8,11,13-triene-4-hydroperoxide (10). An oil, $[\alpha]_{\mathrm{D}}^{25}+16.0^{\circ}\left(\mathrm{CHCl}_{3} ; \quad c 0.75\right)$. IR $v_{\max }^{\text {Neat }} \mathrm{cm}^{-1}: 3363 .{ }^{1} \mathrm{H} \mathrm{NMR}\left(\mathrm{CDCl}_{3}\right): \delta 1.20(s, \mathrm{H}-20)$, $1.21(d, J=6.9 \mathrm{~Hz}, \mathrm{H}-16,17), 1.23(m, \mathrm{H}-3 \alpha), 1.40$ (ddd, $J=14.0,14.0,3.6 \mathrm{~Hz}, \mathrm{H}-1 \alpha), 1.37$ (s, H-18), 1.94 (dd, $J=12.0,3.1 \mathrm{~Hz}, \mathrm{H}-5), 2.10(d d d, J=13.6,12.0,3.8 \mathrm{~Hz}$, $\mathrm{H}-6 \beta), 2.14(m, \mathrm{H}-6 \alpha), 2.20(m, \mathrm{H}-3 \beta), 2.23(m, \mathrm{H}-1 \beta), 2.85$ (sept, $J=6.9 \mathrm{~Hz}, \mathrm{H}-15), 4.81(d d, J=3.8,3.8 \mathrm{~Hz}, \mathrm{H}-7$ ), $7.10(d d, J=8.1,2.0 \mathrm{~Hz}, \mathrm{H}-12), 7.14(d, J=2.0 \mathrm{~Hz}, \mathrm{H}-14)$, $7.19(d, J=8.1 \mathrm{~Hz}, \mathrm{H}-11)$. EI-MS $(70 \mathrm{eV}) \mathrm{m} / \mathrm{z}$ (rel. int.): $304\left[_{\mathrm{M}}{ }^{+}\right.$(40), 287 (9), 271 (7), 269 (8), 254 (27), 253 (100), 211 (45), 187 (26). Exact mass $[\mathrm{M}]^{+}$for $\mathrm{C}_{19} \mathrm{H}_{28} \mathrm{O}_{3}$ requires 304.2039. Found 304.2050.

19-Norabieta-7,13-dien-4-ol (11). An oil, $[\alpha]_{\mathrm{D}}^{25}+62.1^{\circ}$ $\left(\mathrm{CHCl}_{3} ; c 0.1\right)$. IR $v_{\max }^{\text {Neat }} \mathrm{cm}^{-1}: 3484(\mathrm{OH}) .{ }^{1} \mathrm{H}$ NMR $\left(\mathrm{CDCl}_{3}\right): \delta 0.92(s, \mathrm{H}-20), 0.99(d, J=6.8 \mathrm{~Hz}, \mathrm{H}-16), 1.00$ $(d, J=6.8 \mathrm{~Hz}, \mathrm{H}-17), 1.14$ ( $s, \mathrm{H}-18), 2.21$ (sept, $J=6.8 \mathrm{~Hz}, \mathrm{H}-15$ ), 5.43 (br s, H-7), 5.77 (s, H-14). EI-MS $(70 \mathrm{eV}) \mathrm{m} / \mathrm{z}$ (rel. int.): 274 [M] $^{+}(34), 256(83), 241(100)$, 213 (36), 199 (14), 185 (86), 157 (11), 143 (17). Exact mass $[\mathrm{M}]^{+}$for $\mathrm{C}_{19} \mathrm{H}_{30} \mathrm{O}$ requires 274.2298. Found 274.2297.

$13 \beta, 14 \beta$-Epoxy-4-hydroxy-19-norabiet-7-en-6-one (12). An oil, $[\alpha]_{\mathrm{D}}^{25}-57.1^{\circ}(\mathrm{MeOH} ; c 0.14)$. IR $v_{\max }^{\text {Neat }} \mathrm{cm}^{-1}$ : $3525\left(-\mathrm{OH}\right.$ ). 1661 (conjugated $\mathrm{C}=\mathrm{O}$ ): $\mathrm{UV} \lambda_{\max }^{\mathrm{MeoH}} \mathrm{nm}(\varepsilon)$ : $246(10810)$. ${ }^{1} \mathrm{H} \mathrm{NMR}\left(\mathrm{CDCl}_{3}\right): \delta 0.96(d, J=7.0 \mathrm{~Hz}$, $\mathrm{H}-16), 0.99(s, \mathrm{H}-20), 1.01(d, J=7.0 \mathrm{~Hz}, \mathrm{H}-17), 1.32(s$, H-18), 1.66 (sept, $J=7.0 \mathrm{~Hz}, \mathrm{H}-15), 2.30(s, \mathrm{H}-5), 3.22(s$, $\mathrm{H}-14), 3.40(d, J=2.5 \mathrm{~Hz},-\mathrm{OH}), 6.11(d, J=3.0 \mathrm{~Hz}$, H-7). EI-MS (70 eV) $\mathrm{m} / z$ (rel. int.): 304 [M] $^{+}$(77), 290 (21), 289 (100), 286 (19), 271 (20), 243 (29), 219 (22), 147 (30). Exact mass [M] ${ }^{+}$for $\mathrm{C}_{19} \mathrm{H}_{28} \mathrm{O}_{3}$ requires 304.2037. Found 304.2045.

Autoxidation of abieta-8,11,13-trien-19-al. The title compound ( $24 \mathrm{mg}$ ) was dissolved in benzene $(15 \mathrm{ml})$ and stirred at $18^{\circ}$ in the air for 5 days. Solvent was removed, the residue was taken up with $\mathrm{CHCl}_{3}$ and the components were separated by HPLC with elution of hexane-EtOAc $(5: 2)$ to give 4-epidehydroabietic acid (12 mg), norditerpenes $2(3 \mathrm{mg}), 3(3 \mathrm{mg}), 8(2 \mathrm{mg})$ and 4 ( $2 \mathrm{mg})$.

Acknowledgement-We are grateful to the National Science Council of the Republic of China for financial support (NSC 83-0208-M-002-095).

\section{REFERENCES}

1. Ying, S. S. (1985) Coloured Illustrated Flora of Taiwan Vol. 1, p. 168, National Taiwan University, Taipei.

2. Hsu, C. M. (1960) Chemical Constitutents of the Medicinal Plants in Taiwan Vol. 1, p. 174. National Research Institute of Chinese Medicine, Taipei.

3. Sawada, T. (1958) Yakugaku Zasshi 78, 1020.

4. Fang, J.-M., Lee, C.-K. and Cheng, Y.-S. (1992) Phytochemistry 31, 3659.

5. Fang, J.-M., Lee, C.-K. and Cheng, Y.-S. (1993) Phytochemistry 33, 1169.

6. Fang, J.-M., Sou, Y.-C., Chiu, Y.-H. and Cheng, Y.-S. (1993) Phytochemistry 34, 1581.

7. Lee, C.-K., Fang, J.-M. and Cheng, Y.-S. (1994) Phytochemistry 35, 983.

8. Rowe, J. W., Ronald, R. C. and Nagasampagi, B. A. (1972) Phytochemistry 11, 365.

9. Seelye, R. N. and Watkins, W. B. (1969) Tetrahedron 25, 447.

10. Rowe, J. W. and Nagasampagi, B. A. (1971) Phytochemistry 10, 1647.

11. Zhogal'skii, A. N., Azarko, V. A. and Mitskevich, N. I. (1983) Vestsi. Akad. Navuk BSSR, Ser. Khim. Navuk 14.

12. Tanaka, O., Mihashi, S., Yanagisawa, I., Nikaido, T. and Shibata, S. (1972) Tetrahedron 28, 4523. 